\title{
Characterization, detection and identification of transgenic chili pepper harboring coat protein gene that enhances resistance to cucumber mosaic virus
}

\author{
Sang-Gyu Seo · Ji-Seong Kim - Seo-Bum Jeon • Mi-Rae Shin · Seung-Won Kang • Gung-Pyo Lee • \\ Jin-Sung Hong $\cdot$ Chee Hark Ham $\cdot$ Ki Hyun Ryu $\cdot$ Tae-Sung Park $\cdot$ Sun-Hyung Kim
}

Received: 28 October 2009 / Accepted: 18 November 2009

(C) Korean Society for Plant Biotechnology

\begin{abstract}
Previously, two events (H15 and B20) of transgenic pepper (Capsicum annum $\mathrm{L}$.) that enhanced resistance to Cucumber mosaic virus (CMV) by the introduction of CMV coat protein $(\mathrm{CP})$ gene were constructed. Presently, a single copy number of the $\mathrm{CP}$ gene was revealed in $\mathrm{H} 15$ and $\mathrm{B} 20$ by Southern blot. To predict possible unintended effects due to transgene insertion in an endogenous gene, we carried out sequencing of the 5'-flanking region of the $\mathrm{CP}$ gene and a Blastbased search. The results revealed that insertion of the transgene into genes encoding putative proteins may occur in the H15 and B20 transgenic event. Mutiplex polymerase chain reaction (PCR) for simultaneous detection and identification of transgenic pepper was conducted with a set of nine primers. Both transgenic event were differentiated from non-transgenic
\end{abstract}

S.-G. Seo and J.-S. Kim should be considered co-first authors.

S.-G. Seo • J.-S. Kim• S.-B. Jeon • M.-R. Shin • S.-H. Kim (ه) (Department of Environmental Horticulture, The University of Seoul, Jeonnong-dong 90, Dongdaemun-gu, Seoul 130-743,

South Korea)

e-mail: mongdal@uos.ac.kr

S.-W. Kang · G.-P. Lee

(Department of Applied Plant Science, College of Industrial

Science, Chung-Ang University, Anseong-Si, Gyeonggi-Do

456-756, South Korea)

J.-S. Hong $\cdot$ K.-H. Ryu

(Plant Virus Bank, Division of Environmental and Life Science,

Seoul Women's University, Seoul 139-774, South Korea)

C.-H Harn

(Biotechnology Institute, Nongwoo Bio Co., Ltd, Yeoju, Gyeonggi, South Korea)

T.-S. Park

(Rural Development Administration, Suwon 441-707, Korea) event by the presence of $267 \mathrm{bp}$ and $430 \mathrm{bp}$ PCR products indicative of $\mathrm{CP}$ gene specific primer pairs and primer pairs targeting the $\mathrm{CP}$ gene and $35 \mathrm{~S}$ promoter. $\mathrm{H} 15$ and $\mathrm{B} 20$ uniquely possessed $390 \mathrm{bp}$ and $596 \mathrm{bp}$ PCR product, respectively. The presence of a $1115 \mathrm{bp}$ product corresponding to intrinsic pepper actin gene confirmed the use of pepper DNA as the PCR template. The primer set and PCR conditions used presently may allow the accurate and simple identification of CMV resistant transgenic pepper.

Keywords Capsicum annum L., Cucumber mosaic virus, GMO, Multiplex PCR

\section{Introduction}

Since transgenic plants were first commercialized in 1997, their global use has progressively increased, exceeding 50fold as of 2005. Transgenic soybean, maize, cotton and canola constitute almost $100 \%$ of the cultivated area of transgenic crops, with the remainder being comprised of Bacillus thuringiensis rice and virus resistant squash and papaya (James et al. 2005). Since the introduction of transgenic crops, concern has been expressed about the consequences of the unintentional environmental introduction of transgenic genes. Transgenic introduction of a gene can potentially influence the function of the surrounding sequence (insertion effect) or visa versa (position effect). The unintended effect of DNA insertion can be partly predicted on the basis of knowledge concerning the location and function of the inserted DNA (Kuiper et al. 2001). 
Multiplex polymerase chain reaction (PCR), which is performed by use of a combination of several primer pairs in the same reaction tube, produces more information in a shorter time than single end point PCR with less consumption of reagents (Germini et al. 2004). Since its first description in 1988, this method has been successfully applied in many areas of DNA testing (Henegariu et al. 1997). Recently, several studies have exploited multiplex PCR for the efficient and reliable detection and/or identification of transgenic sugar beet shoots (Mannerliöf and Tenning 1997), and genetically modified varieties of maize (Matsuoka et al. 2001, James et al 2003), canola and soybean (James et al. 2003).

Previously, transgenic pepper eventtolerant to the new pathotype Cucumber mosaic virus CMVP1 was developed by genetic transformation of a coat protein (CP) gene from CMVP0 (Lee et al. 2009). The present study was undertaken to provide more information about newly developed transgenic pepper event. Specifically, we carried out DNA blot analysis to determine the transgene copy number, performed sequencing of the flanking regions of the inserted DNA to predict unintended effects in transgenic event and used multiplex PCR to detect two transgenic event and also to identify each two event.

\section{Materials and Methods}

\section{DNA isolation}

Genomic DNA was isolated from leaf tissues of the non-transgenic event \#2377 (parental eventof H15) and \#915 (parental event of B20), and from the transgenic event $\mathrm{H} 15$ and B20 as previously described (Kim and Hamada 2005). Sample genomic DNA concentration was determined by measuring the ultraviolet (UV) absorption at $260 \mathrm{~nm}$ and purity was ascertained by measuring the absorbance due to protein at $280 \mathrm{~nm}$ and 230 $\mathrm{nm}$, and calculating the A260/A280 and A260/A230 ratios. All measurements utilized a Beckman DU 700 UV/vis spectrophotometer (Beckman Instruments, Fullerton, CA)

Southern blot analysis

Genomic DNA (30 g) was digested with EcoR and HindIII to cut the inserted CP gene. The resulting DNA fragments were separated by electrophoresis on a $0.8 \%$ agarose gel and theresolved fragments were transferred to a positive-charged nylon membrane (Roche Molecular Biochemicals, Mannhein, Germany) by capillary transfer using $0.4 \mathrm{~N} \mathrm{NaOH}$. DNA probes for the NPTII or CMV CP gene cDNA wereprepared from digoxigenin-PCR probe synthesis kit (Roche Molecular Biochemicals), Pre-hybridization, hybridization, and post-hybrid- ization procedures were done according to the manufacturer's instructions.

PCR-based genome walking

Genomewalking was performed using the protocol supplied by the vendor of the GenomeWalker Universal kit (Clontech Laboratories, Palo Alto, CA). Genomic DNA was digested with $A l u \mathrm{I}, D r a \mathrm{I}, E c o \mathrm{RV}, H p a \mathrm{I}, P v u \mathrm{II}$ and $S t u \mathrm{I}$, and was ligated with the GenomeWalker adaptor (Clontech Laboratories). PCR were carried out using each enzyme-digested DNA library, $10 \mathrm{pM}$ AP1 primer, $10 \mathrm{pM} \mathrm{CP}$ gene specific reverse primer, $0.2 \mathrm{mM}$ dNTP mixture, $2.5 \mathrm{U}$ of EX Taq polymerase (TaKaRa Shiga, Japan) and 10× EX Taq buffer (TaKaRa) in a $50 \mu 1$ reaction volume using a xp thermal cycler (Bioer Technology, Hangzhou, China). Cycling condition consisted of 5 cycles of $94^{\circ} \mathrm{C}$ for $25 \mathrm{~s}$ and $72^{\circ} \mathrm{C}$ for 3 min followed by 20 cycles of $94^{\circ} \mathrm{C}$ for $25 \mathrm{~s}$ and $67^{\circ} \mathrm{C}$ for $3 \mathrm{~min}$, with a final cycle at $67^{\circ} \mathrm{C}$ for $7 \mathrm{~min}$. Semi-nested PCR was performed under the same conditions using $1 / 10$ of the primary PCR product as DNA template and using the AP2 primer.

Multiplex PCR and sequencing of PCR product

Multiplex PCR reactions were carried out in thepresence of $40 \mathrm{ng}$ of genomic DNA, $10 \mathrm{pM}$ of the five primer pairs, 0.2 $\mathrm{mM}$ dNTP mixture, $1.5 \mathrm{U}$ of EX Taq polymerase and 10x EX Taq buffer in a $50 \mu 1$ reaction volume. Thermal cycling was using the aforementioned $x p$ thermal cycler at $94^{\circ} \mathrm{C}$ for $3 \mathrm{~min}$ for predenaturation, 35 cycles of $94^{\circ} \mathrm{C}$ for $30 \mathrm{~s}, 60^{\circ} \mathrm{C}$ for $30 \mathrm{~s}$ and $72^{\circ} \mathrm{C}$ for $1 \mathrm{~min}$, with a final cycle at $72^{\circ} \mathrm{C}$ for $5 \mathrm{~min}$. The amplified PCR products were separated by electrophoresis on a $0.8 \%$ agarose gel. To identify optimal condition of multiplex PCR, the concentration of each primer was adjusted depending on the linear range of PCR amplification prior conducted. Each PCR fragment was ligated into a T\&A vector (Real Biotech, Taipei, Taiwan) and sequenced. The obtained sequence was aligned with vector and/or flanking region sequence with the CLC Sequence Viewer 6.0.2 program (CLC bio, Katrinebjerg, Denmark) and the kalign program (http:// www.ebi.ac.uk/Tools/kalign/)

\section{Results and Discussion}

Southern hybridization

DNA blot analyses were performed with probe derived from the CP gene and NPTII kanamycin resistant gene. When genomic DNA digested with EcoRI and HindIII was hybridized 

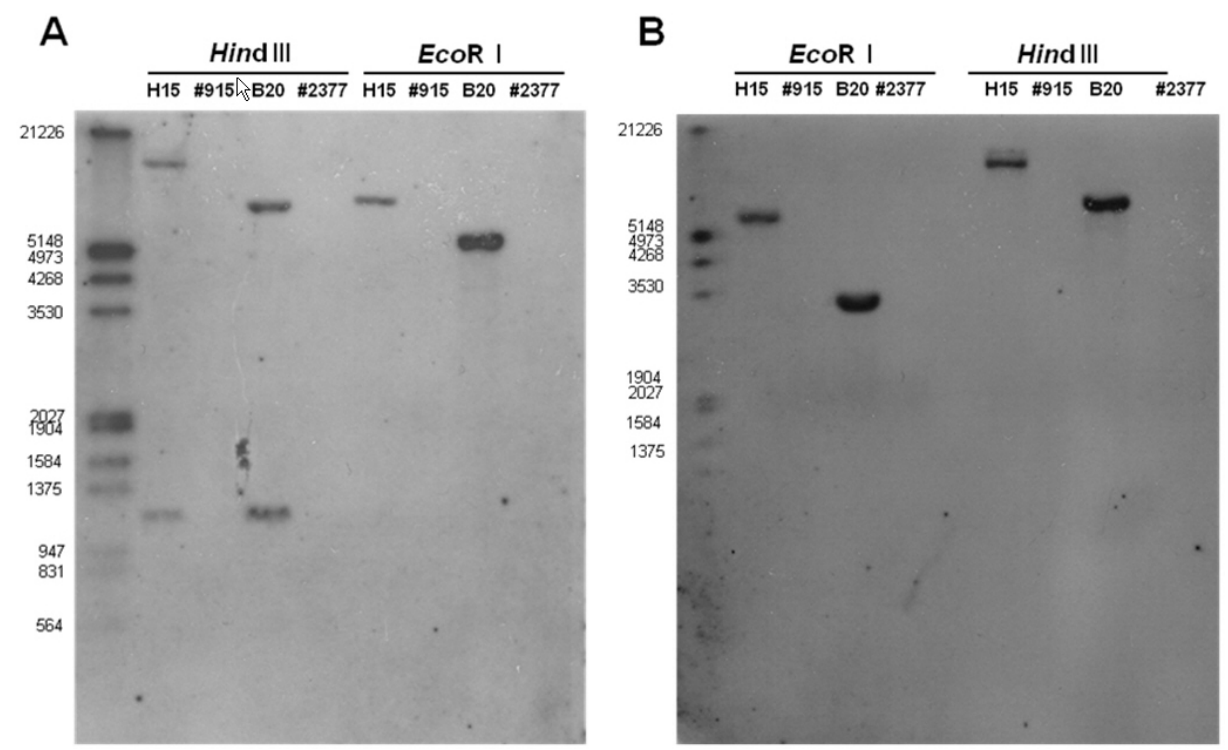

Fig. 1 Southern blot analysis of transgenic pepper and non-transgenic pepper. (A) Hybridization with coat protein specific probe. (B) Hybrization with NPTII gene for kanamycin resistance specific probe

with NPTII specific probe, a single band was evident in the H15 and B20 transgenic event, but no band was discernable in the parental event (Fig. 1). Hybridization with the CP gene specific probe also produced a single band when digested with EcoRI but two bands were apparent when digested with Hind III. This is explainable because the CP gene specific probe was made from full CP gene DNA sequence and the CP gene in the genomic DNA of transgenic plants contains one Hind III restriction site.

Flanking region and prediction of unintended effect

In Agrobacterium-mediated transformation, insertion of transferred DNA with specific plant genomic DNA sequences occurs randomly and can produce unusual, insertion-related outcomes. The unusual changes of transgenic plants canbe detected by morphological and chemical analyses, although this approach can be onerous and is hindered by incomplete knowledge of unknown plant traits or chemicals. Localization of insertion location is most direct approach to predicting and identifying the possible occurrence of unintended effects; this can be achieved by direct sequencing of flanking DNA, despite the still-limited knowledge of plant genomes(Kuiper et al. 2001). The 5'-flanking sequence of the transgene in the H15 and B20 transgenic event were determined by PCR-based genome walking. Flanking sequences of about 3000 bp in $\mathrm{H} 15$ and 1000 bp in B20 were obtained. A 300 bp DNA flanking region adjacent to the vector region was used to determine the insertion site (Fig. 2). These processes were performed by searching known DNA sequences in an expressed sequence tag database using the BLAST algorithm. The search revealed that the $\mathrm{H} 15$ transgene could be inserted into or adjacent to unidentified Capsicum annuum cDNA (Genebank accession no. GD102816 or CO907187). But, no significant similarity was found in a nucleotide database. The B20 transgene also was capable of similar insertions involving an ortholog in pepper of unidentified tomato or potato cDNA (Genebank accession nos. BG627797, CV505761, BG097242, or BI434579), and the insertion site displayed significant similarity with mRNA from root of Solanum lycopersicum. Thus, unintended effects are conceivable using the H15 and B20 event, and may be at least partly predictable based on knowledge of the insertion location, defined as a loss of function of the gene in the insertion region.

Multiplex PCR for detection and identification of transgenic plants

Detection of transgenic plants can be conducted by proteinbased method such as Western blot and enzyme-linked immunosorbant assay (ELISA), or DNA-based methods includeing Southern blot and PCR (Ahmed 2002). Western and Southern blots and ELISA are highly specific but suffer from being comparatively time-consuming, costly and technical. In contrast, the PCR-based approach, especially multiplex PCR, is a simple and sensitive means of distinguishing transgenic plants (Yamaguchi et al. 2003). Multiplex PCR has been used to detect or identify three major transgenic crops: soybean (Roundup ready), maize (MON810, Bt11, event 176, T14/25 and GA21) canola (GT73, HCN92/28, MS8/RF3, Oxy235) (James et al. 2003, Margarit et al. 2005, Germini et al. 2004, Matsuoka et al. 2001, Yamaguchi et al. 2003). 
A

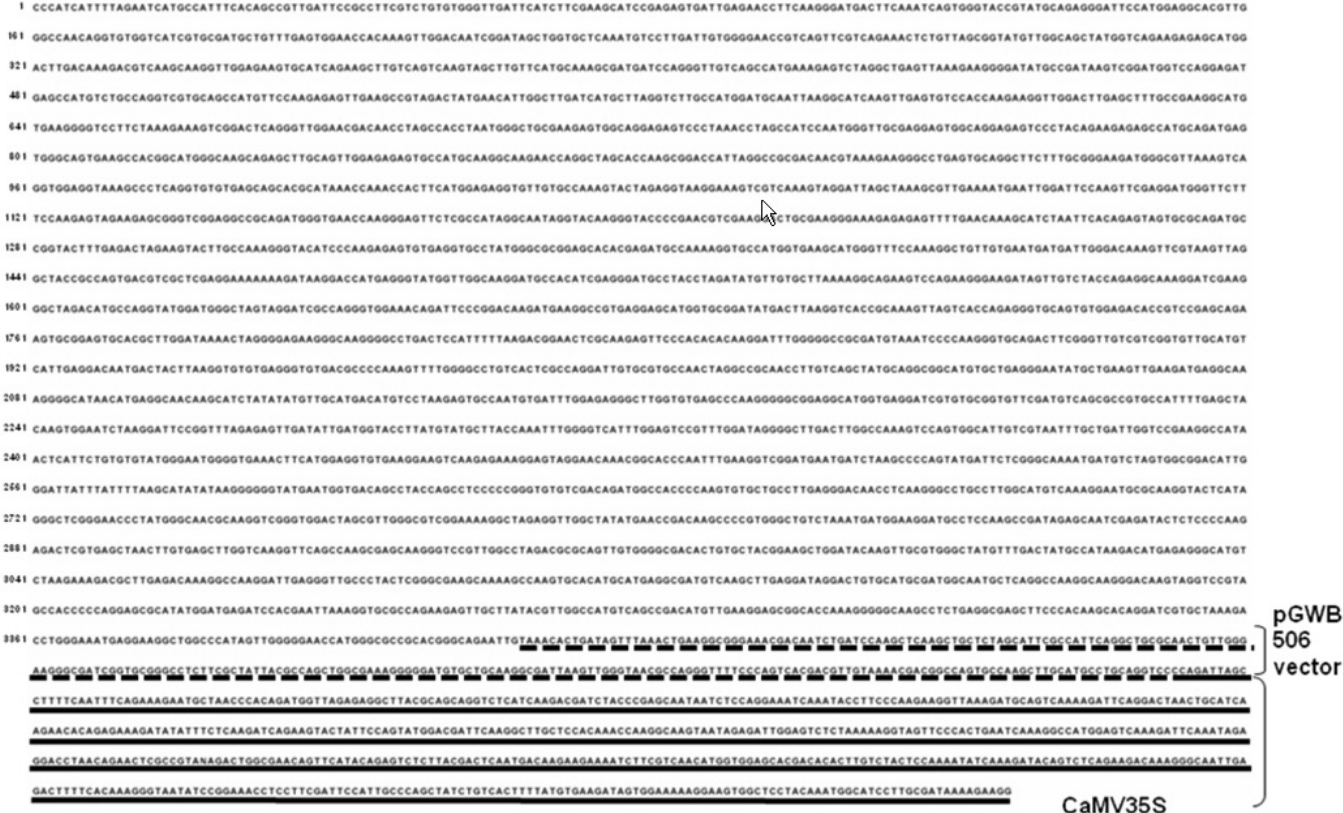

B

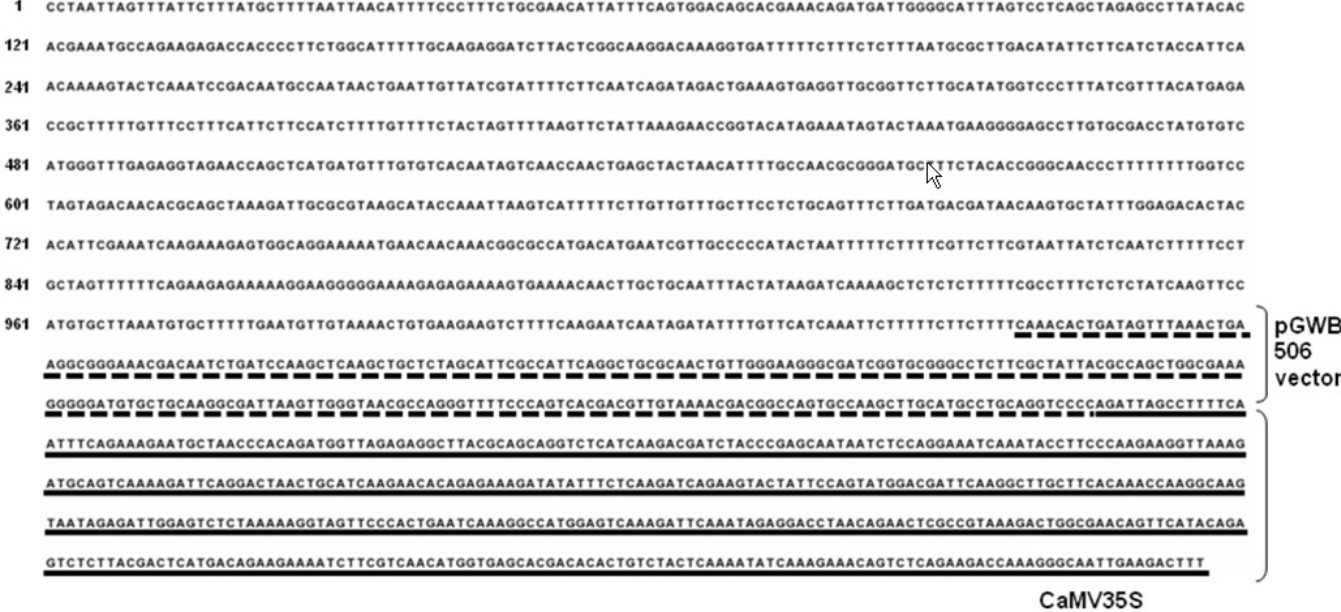

Fig. 2 Sequence of $5^{\prime}$-flanking region of transgene in the H15 (A) and B20 (B) transgenic pepper event

In this study, an efficient and simple detection and identification for virus tolerant pepper (Lee et al. 2009) was developed using the multiplex PCR system. Since efficiency of the amplification is affected by contamination of purified DNA (Hamill et al. 1991), purity of extracted genomic DNA was checked. Only high purity DNA, presenting A260/A280 and A260/A230 ratios exceeding 1.8 and 2.7, respectively, were used. Becausethe optimum condition for multiplex PCR appear to depend more on the primer combination (James et al. 2003), PCR reactions was conducted with five primer pairs (Table 1 and Fig. 3a) to verify the specificity of each primer pair. The concentration of each primer was adjusted depending on the linear range of PCR amplification. Five primer targets vectors were used to differentiate transgenic eventfrom nontransgenic event. Especially, two specific sense primers, pepper $15 \mathrm{~F}$ for $\mathrm{H} 15$ event and pepper $20 \mathrm{~F}$ for $\mathrm{B} 20$ event, which target the flanking region of each event, were used to identify the $\mathrm{H} 15$ and B20 event. Also, two specific primers for intrinsic pepper actin gene were used to confirm that the pepper DNA was used as the template for multiplex PCR.

In both the $\mathrm{H} 15$ and $\mathrm{B} 20$ event, $\mathrm{CP}$ gene $\mathrm{R} 2$ (antisense primer) targeted the $\mathrm{CP}$ gene and $\mathrm{P} 35 \mathrm{~S} \mathrm{~F}$ (sense primer) targeted the 35 s promoter primer pairs, $\mathrm{CP}$ gene $\mathrm{F}$ and $\mathrm{CP}$ gene $\mathrm{R}$ primer pairs targeted the $\mathrm{CP}$ gene, and Pepper actin $\mathrm{F}$ and Pepper actin $\mathrm{R}$ primer pairs targeted the gene encoding actin, with the amplified PCR products being $267 \mathrm{bp}, 430 \mathrm{bp}$, and $1115 \mathrm{bp}$ respec- 
Table 1 Sequence and concentration of primers and template DNA concentration for the multiplex PCR.

\begin{tabular}{|c|c|c|c|c|}
\hline Template DNA (ng) & Primer name & Sequence $\left(5^{\prime}-3^{\prime}\right)$ & Primer concentration (pmol) & Product length (bp) \\
\hline \multirow{10}{*}{40} & Actin F & ATGGCAGATGAAGATATTCA & 15 & \multirow{2}{*}{1115} \\
\hline & Actin R & GCACTGTATGACTGACACCA & 15 & \\
\hline & $\mathrm{CP}$ gene $\mathrm{F}$ & GTAGGGAGTGAACGCTGTAGACC & 6 & \multirow{2}{*}{430} \\
\hline & $\mathrm{CP}$ gene $\mathrm{R}$ & GAAGTACTAGCTCGTCCGTCTCG & 6 & \\
\hline & $\mathrm{P} 35 \mathrm{~s} F$ & ACTATCCTTCGCAAGACCCTTC & 14 & \multirow{2}{*}{267} \\
\hline & CP gene R2 & CTACAGCGTTCACTCCCTACAAAG & 14 & \\
\hline & Pepper $15 \mathrm{~F}$ & CACAGGATCGTGCTAAAGACCT & 14 & \multirow{2}{*}{390} \\
\hline & P35s R & GTAAGCCTCTCTAACCATCTGTGG & 5 & \\
\hline & Pepper $20 \mathrm{~F}$ & GCCATGACATGAATCGTTGC & 10 & \multirow{2}{*}{596} \\
\hline & P35s R & GTAAGCCTCTCTAACCATCTGTGG & 5 & \\
\hline
\end{tabular}

A
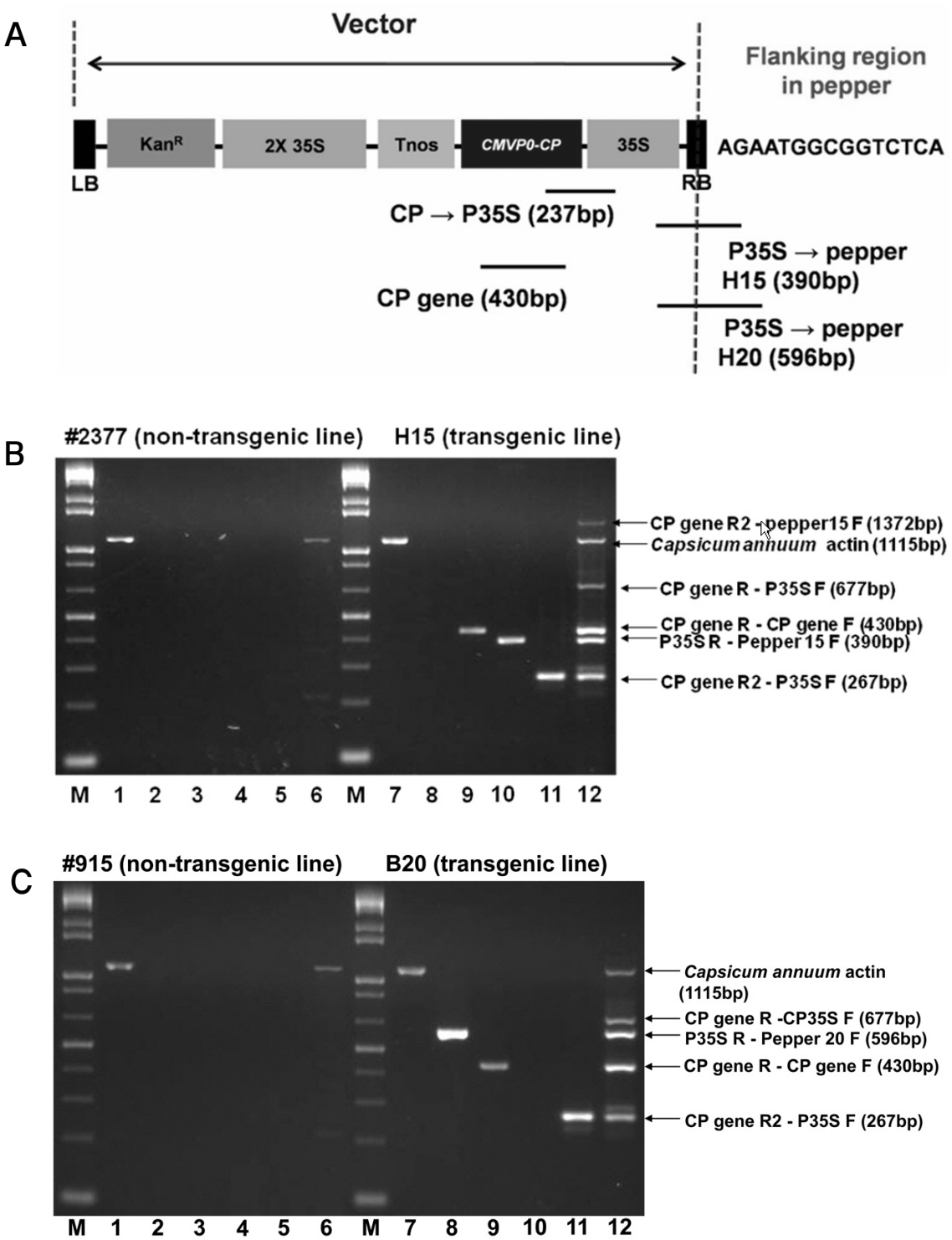

Fig. 3 Multiplex PCR analysis. (A) Primer design for multiplex PCR. (B,C) Multiplex PCR detection and identification of two transgenic peppers. Lanes: M, $1 \mathrm{~kb}$ marker 1 and7, actin (1115 bp) 2 and 8, P35S-B20 flanking region (596 bp) 3 and 9 , CP gene (430 bp) 4 and 10, P35S-H15 flanking region (390 bp) 5 and 11, CP gene-P35S (267bp) 6 and 12, multiplex PCR by a set of nine primers 
tively. But, in non-transgenic event, only the $1115 \mathrm{bp}$ of PCR product appeared (Figs. 3). Additionally, a 390 bp PCR was apparent only from the DNA template of H15. In B20, a PCR product of $596 \mathrm{bp}$ was apparent.

The CP gene $\mathrm{R}$ primer resulted in a 430 bp product with $\mathrm{CP}$ gene $\mathrm{F}$ (expected) and 677 bp product with P35S-F (unexpected) in both transgenic event, while the $\mathrm{CP}$ gene $\mathrm{R} 2$ primer resulted in a $1372 \mathrm{bp}$ product with pepper $15 \mathrm{~F}$ (unexpected) product only in the $\mathrm{H} 15$ event. These results confirmed the specificity of two reverse primer targeting the CP gene se-
A
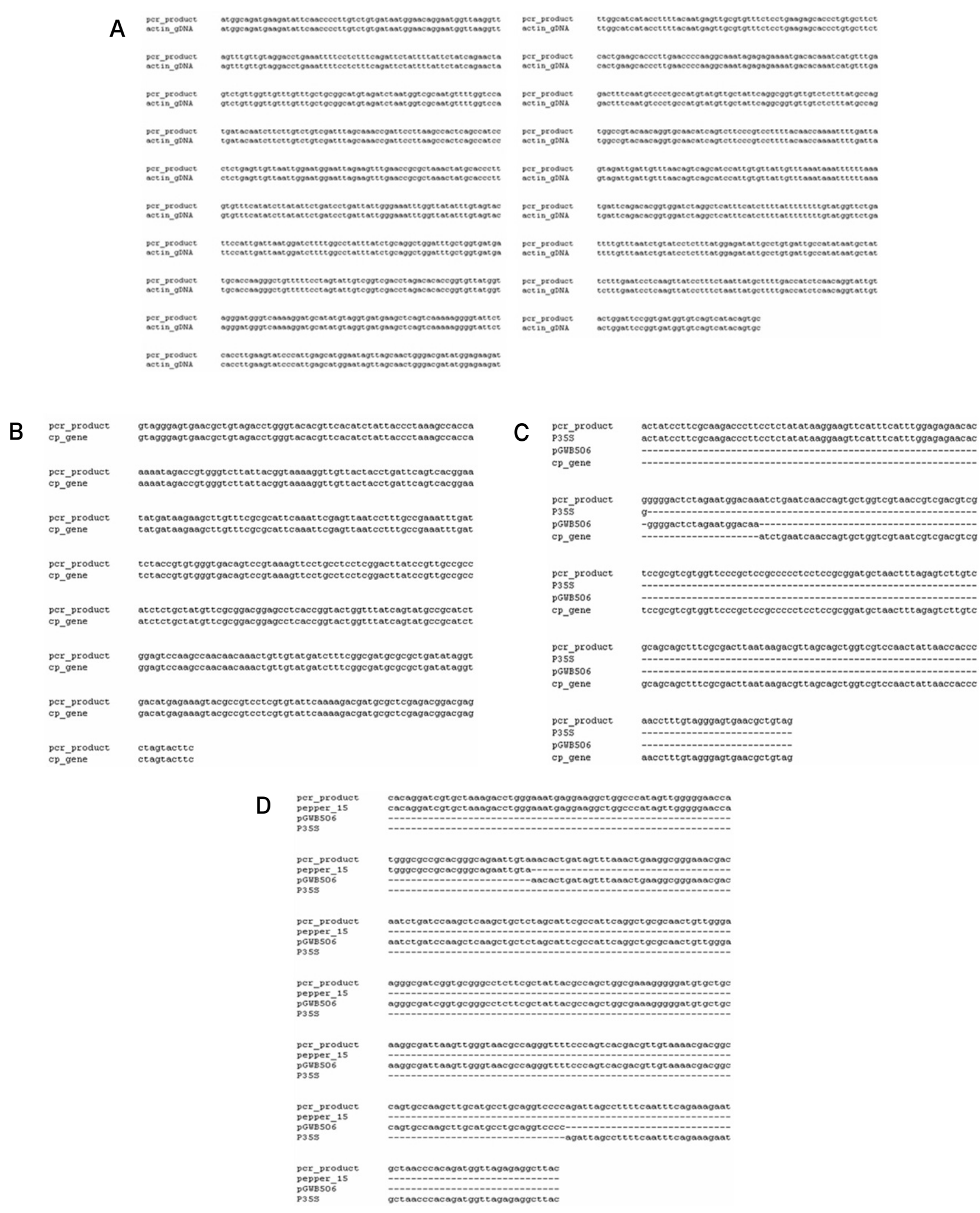

-



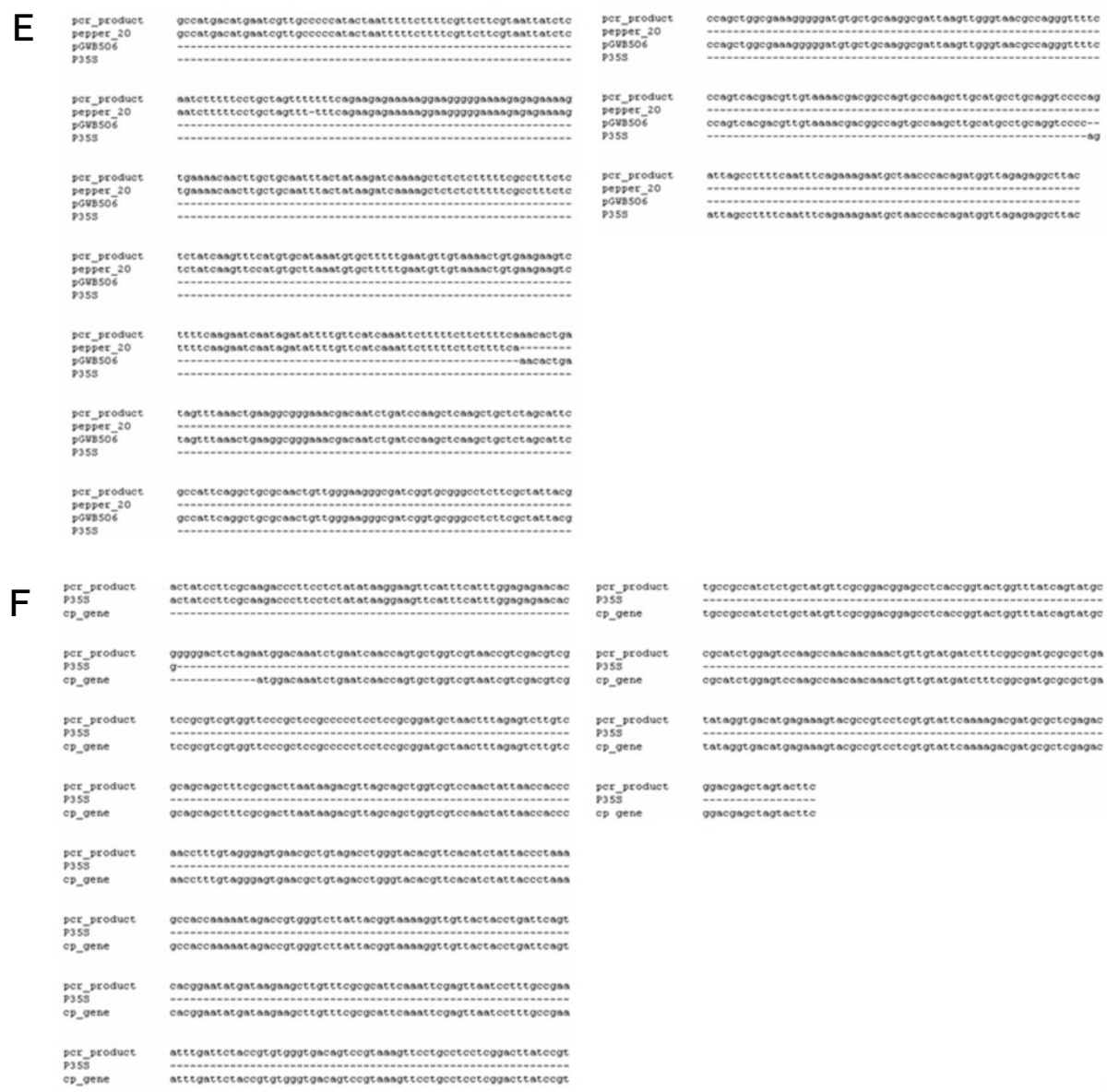

goacgagetagtacte

G
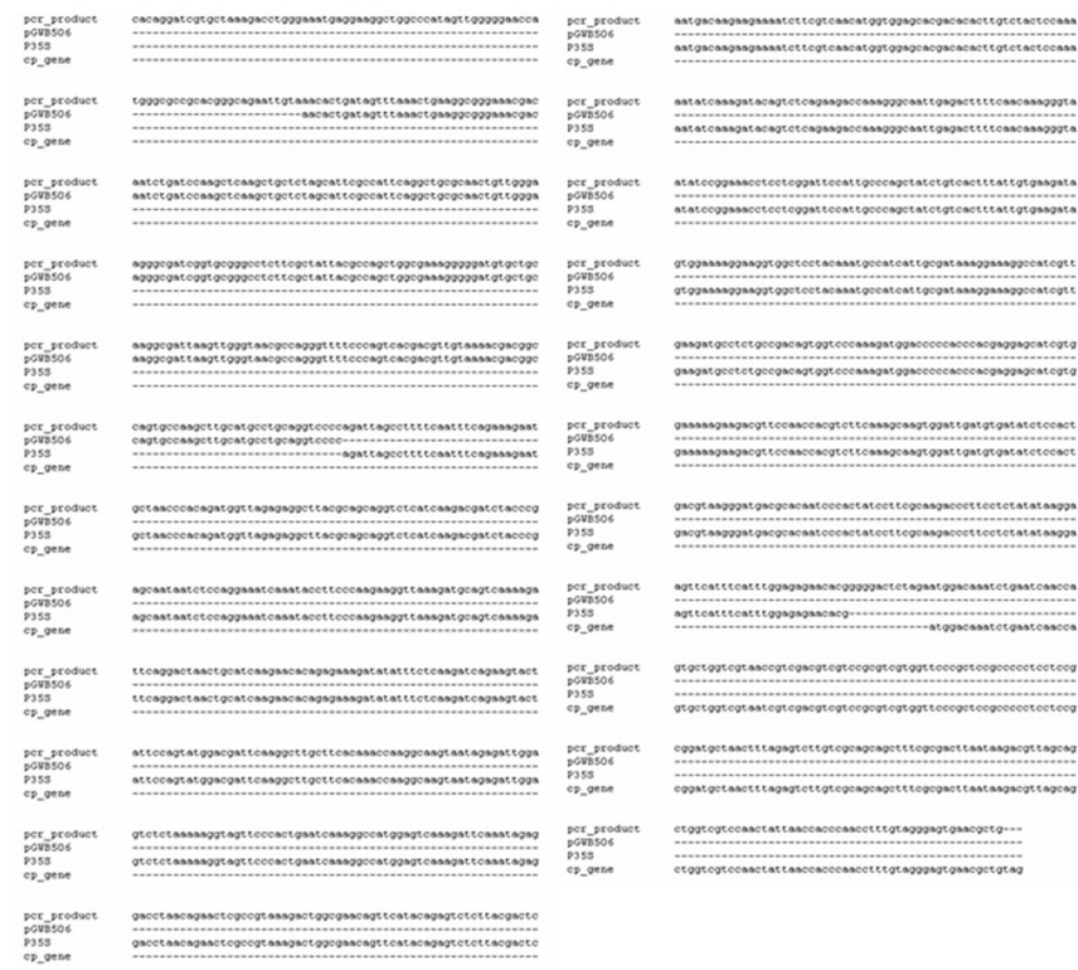

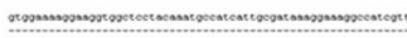

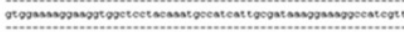

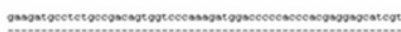

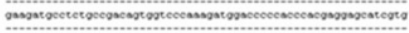

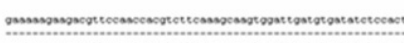

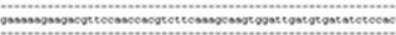

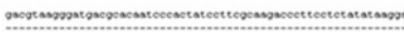

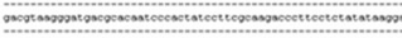
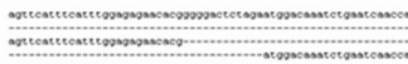

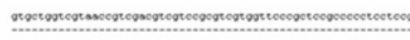

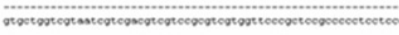

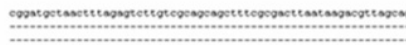

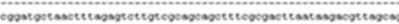

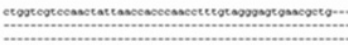

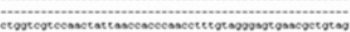

Fig. 4 Sequence comparison between PCR product and transgenic event harboring gene. (A) Actin (1115 bp). (B) CP gene (430 bp). (C) CP gene - P35S (267 bp). (D) P35S-pepper 15 flanking region (390 bp). (E)P35S-pepper 20 flanking region (596 bp). (F) cp gene-P35S (677 bp). (G) Cp gene- pepper 15 flanking region (1372 bp) 
quence and so the reliability of our results, and also reveal another difference between the H15 and B20 event.

Cloning and sequencing of each band fractionated by electrophoresis was next performed. The sequence data confirmed that each band was due to primers used in this study, with each PCR product containing theproper sequence of vector and/or flanking sequence of the transgenic event (Fig. 4). Ideally, a multiplex PCR system capable of detecting transgenic plant targets like promoter and/or selection markers that is also capable of identifying specific event would be user-friendly and capable of simplifying the process of transgenic crop detection and identification (James et al. 2003). Also, the use of specific primer pairs targeting both the transgene and the flanking region of each transgenic event provides reliability because the possibility of missed analysis due to spontaneously infected virus is excluded.

\section{Conclusion}

We used primer pairs targeting promoter and transgene, and primers specificity targeted to both transgenic event, the efficient, reliable and simple detection and identification of virus resistance pepper transgenic event was achieved. A set of nine primers and PCR conditionsused in this study may offer appropriate and simple detection and identification against virus resistance pepper transgenic event.

Acknowledgments This work was supported by Biogreen 21 Program (20070301034010).

\section{References}

Ahmed FE (2002) Detection of genetically modified organisms in foods. Trends in Biotech 20:215-223
Ezequiel M, Reggiardo, Vallejos RH, Permingeat HR (2006) Detection of BT transgenic maize in foodstuffs. Food Res Inter 39: 250-255

Germini A, Zanetti A, Salati C, Rossi S, Forreä C, Schmid S, Marchelli R (2004) Development of a seven-target multiplex PCR for the simultaneous detection of transgenic soybean and maize in feeds and foods. J Agric Food Chem 52:3275-3280

Hamill JD, Rounsley S, Spencer A, Todd G, Rhodes MJ (1991) The use of polymerase chain reaction in the plant transformation studies. Plant Cell Rep 10:221-224

Henegariu O, Heerema NA, Dlouhy SR, Vance GH, Vogt PH(1997) Multiplex PCR: critical parameters and step-by-step protocol. BioTech 23:504-511

James C (2005) Global status of commercialized biotech/GM crops. ISAAA Briefs NO 34 ISAAA Ithaca NY

James D, Schmidt AM, Wall E, Green M, Masri S (2003) Reliable detection and identification of genetically modified maize, soybean, and canola by multiplex PCR analysis. J Agric Food Chem 51:5829-5834

Kim SH, Hamada T (2005) Rapid and reliable method of extracting DNA and RNA from sweet potato, Ipomoea batatas (L.) Lam. Biotech Lett 27:1841-1845

Krysan PJ, Young JC, Sussman MR (1999) T-DNA as an insertional mutagen in Arabidopsis. Plant Cell 11:2283-2290

Kuiper HA, Kleter GA, Noteborn HPJM, Kok EJ (2001) Assessment of the food safety issues related to genetically modified foods. Plant J 6:503-528

Lee YH, Jung M, Shin SH, LeeJH, Choi SH, Her NH, Lee JH, Ryu KH, Paek KY, Harn CH (2009) Transgenic peppers that are highly tolerant to a new CMV pathotype. Plant Cell Rep 28:223232

Mannerliöf M, Tenning P (1997) Screening of transgenic plants by multiplex. Plant Mol Biol. Rep. 15: 38-45

Matsuoka T, Kuribara H, Akiyama H, Miura H, Goda Y, Kusakabe Y, Isshiki K,Toyoda M, Hino A (2001) A multiplex PCR method of detecting recombinant DNAs from five lines of genetically modified maize. J Food Hyg Soc Jpn 42:24-32

Yamaguchi H, Sasaki K, Umetsu H, Kamada H(2003) Two detection methods of genetically modified maize and the state of its import into Japan. Food Control 14:201-206 